Fermi National Accelerator Laboratory

\title{
Overview of Accelerators in Medicine
}

\author{
Arlene J. Lennox \\ Fermi National Accelerator Laboratory and Rush University \\ P.O. Box 500, Batavia, Illinois 60510
}

June 1993

Presented at the 1993 Particle Accelerator Conference, Washington, D.C., May 17-20, 1993 


\section{Disclaimer}

This report was prepared as an account of work sponsored by an agency of the United States Government. Neither the United States Government nor any agency thereof, nor any of their employees, makes any warranty, express or implied, or assumes any legal liability or responsibility for the accuracy, completeness, or usefulness of any information, apparatus, product, or process disclosed, or represents that its use would not infringe privately owned rights. Reference herein to any specific commercial product, process, or service by trade name, trademark, manufacturer, or otherwise, does not necessarily constitute or imply its endorsement, recommendation, or favoring by the United States Government or any agency thereof. The views and opinions of authors expressed herein do not necessarily state or reflect those of the United States Government or any agency thereof. 


\title{
Overview of Accelerators in Medicine
}

\author{
Arlene J. Lennox \\ Fermi National Accelerator Laboratory* and Rush University \\ P.O. Box 500, MS 301, Batavia, Illinois 60510-0500 USA
}

\begin{abstract}
Accelerators used for medicine include synchrotrons, cyclotrons, betatrons, microtrons, and electron, proton, and light ion linacs. Some accelerators which were formerly found only at physics laboratories are now being considered for use in hospital-based treatment and diagnostic facilities. This paper presents typical operating parameters for medical accelerators and gives specific examples of clinical applications for each type of accelerator, with emphasis on recent developments in the field.
\end{abstract}

\section{INTRODUCTION}

Advances in diagnostic and therapeutic radiology have historically been coupled with advances in physics research. In many cases a new medical procedure is tried using equipment originally designed for physics research. Sometimes the medical use is parasitic to the physics use and at other times the equipment is turned over to medical researchers when it is no longer useful to physics researchers. Thus, when one studies, for example, a new form of radiation therapy it is possible to find several different types of accelerator being used for the same therapy.

When the therapy moves from the research stage to standard practice and it is time to design a dedicated, optimized system it is difficult to tell whether certain parameters are essential or simply there because the accelerator was designed for another purpose. It is also difficult for the accelerator designer to ascertain intensity requirements because medical accelerators are generally specified in terms of dose rate to a volume of tissue. This means that dosimetry techniques and the efficiencies associated with processes such as extraction, targeting, degrading, modulating and energy selection must be well understood before the machine can be designed.

In this presentation intensities and energies are discussed in terms of the current and particle type in the accelerator rather than dose rate and particle delivered to the patient. Typical operating parameters for accelerators which have been used for medical applications are given in Table 1. Design parameters for accelerators in the proposal or development stages are listed in Table 2.

\section{ELECTRON ACCELERATORS}

Conventional radiation therapy directs a beam of photons or electrons at a cancerous tumor. These beams are typically produced by betatrons, microtrons or radiofrequency electron linacs. Betatrons are gradually being replaced by electron linacs because the linacs can be mounted in a gantry which rotates a full $360^{\circ}$ around the patient. State of the art electron linacs operate in two modes, a high intensity mode in

\footnotetext{
*Operated by the Universities Research Association, Inc., under contract No. DE-AC02-76CHO3000 with the U. S. Department of Energy.
}

which electrons strike a tungsten target to produce photons for photon therapy and a low intensity mode in which electrons are directed to the patient for electron therapy. Racetrack microtrons provide electron beams for multiple treatment rooms. In this case the electrons are accelerated in the microtron and a beam transport system is mounted in the gantry. The controls systems for medical electron accelerators are becoming very sophisticated, allowing therapists to preprogram beam energy, collimator size and gantry angle so that these can be adjusted automatically by computer during a treatment.

Ordinary diagnostic $x$-rays are produced by $10-50 \mathrm{keV}$ electrons striking a tungsten target. Normally these electrons are produced by a compact electron gun, but obtaining high quality images of cardiac blood vessels using the iodine $\mathrm{K}$ absorption edge requires an intense monochromatic beam not available from a conventional $x$-ray machine. Electron synchrotrons operating at $2-3 \mathrm{GeV}$ are a good source of this characteristic radiation for angiography.

\section{CIRCULAR PROTON AND DEUTERON ACCELERATORS}

Because of their mature technology it is not surprising that cyclotrons have been used for many medical applications. In particular, great strides have been made in producing isotopes for radiopharmaceuticals. For generating many isotopes it is no longer necessary to share a beam line with physics researchers because commercially available cyclotrons may be dedicated to this task. Hospital-based cyclotrons are also used for fast neutron therapy. At present, cyclotrons for proton and pion therapy are associated with physics laboratories, but increased interest in proton therapy has led to interest in developing hospital-based cyclotrons for proton therapy.

Synchrotrons for proton therapy can be found in both hospital and physics laboratory settings. Light ion therapy typically involves beams of helium, carbon, argon, silicon or neon ions and is available at synchrotrons associated with physics laboratories.

\section{PROTON AND ION LINACS}

Recent advances in the technology of proton linacs, and particularly the use of $425 \mathrm{MHz}$ radiofrequency systems, have made it possible to build smaller accelerators which are increasingly easier to maintain. For this reason linacs are beginning to compete with cyclotrons for isotope production and radiation therapies which involve a primary beam striking a production target to generate a secondary treatment beam. At present proton linacs at national laboratories are being used for fast neutron therapy and isotope production but it is possible to move these activities to the private sector by taking advantage of the new technology. Radiofrequency quadrupole 
Table 1

Medical Accelerator Applications Which Have Already Been Used Clinically

\begin{tabular}{|c|c|c|c|c|}
\hline Accelerator & Application & $\begin{array}{c}\text { Typical } \\
\text { Kinetic Energy }\end{array}$ & $\begin{array}{c}\text { Typical } \\
\text { Average Current }\end{array}$ & Production Reaction \\
\hline Electron Linac & $\begin{array}{l}\text { Electron therapy } \\
\text { Photon Therapy }\end{array}$ & $\begin{array}{l}\text { 4-25 } \mathrm{MeV} \mathrm{e}^{-} \\
\text {4-25 } \mathrm{MeV} \mathrm{e}^{-}\end{array}$ & $\begin{array}{l}100-500 \mathrm{nA} \\
20-150 \mu \mathrm{A}\end{array}$ & $e^{-}+w$ \\
\hline $\begin{array}{l}\text { Microtron \& } \\
\text { Betatron }\end{array}$ & $\begin{array}{l}\text { Electron Therapy } \\
\text { Photon Therapy }\end{array}$ & $\begin{array}{l}\text { 4-20 } \mathrm{MeV} \mathrm{e}^{-} \\
4-50 \mathrm{MeV} \mathrm{e}^{-}\end{array}$ & $\begin{array}{l}100-500 \mathrm{nA} \\
20-150 \mu \mathrm{A}\end{array}$ & $\mathrm{e}^{-}+\mathrm{W}$ \\
\hline $\mathrm{e}^{-}$Synchrotron & Angiography & $2-3 \mathrm{GeV} \mathrm{e}^{-}$ & $250 \mathrm{~mA}$ & $\begin{array}{l}\text { Wiggler-extracted } 33 \\
\qquad \operatorname{keV} \gamma\end{array}$ \\
\hline Cyclotron & $\begin{array}{c}\text { Radioisotopes } \\
\text { Fast Neutron Therapy } \\
\text { Pion Therapy } \\
\text { Proton Therapy }\end{array}$ & $\begin{array}{c}10-100 \mathrm{MeV} p \\
50-75 \mathrm{MeV} \text { por d } \\
500-600 \mathrm{MeV} \text { p } \\
70-185 \mathrm{MeV} \mathrm{p}\end{array}$ & $\begin{array}{c}50-100 \mu \mathrm{A} \\
20-30 \mu \mathrm{A} \\
20-150 \mu \mathrm{A} \\
20-40 \mathrm{nA}\end{array}$ & $\begin{array}{l}p \text { or } d+B e \\
p+B e \text { or } C\end{array}$ \\
\hline p Synchrotron & $\begin{array}{l}\text { Proton Therapy } \\
\text { Light Ion Therapy }\end{array}$ & $\begin{array}{c}70-250 \mathrm{MeV} \text { p } \\
225-670 \mathrm{MeV} / \mathrm{amu}\end{array}$ & $\begin{array}{c}20-40 \mathrm{nA} \\
10^{8}-10^{10} \text { ions } / \mathrm{sec}\end{array}$ & \\
\hline RFQ Linac & Injector for Synchrotron & $2.0 \mathrm{MeV} \mathrm{p}$ & up to $150 \mu \mathrm{A}$ & \\
\hline Proton Linac & $\begin{array}{c}\text { Fast Neutron Therapy } \\
\text { Radioisotopes } \\
\text { Pion Therapy }\end{array}$ & $\begin{array}{c}66 \mathrm{MeV} \text { p } \\
10-800 \mathrm{MeV} \text { p } \\
800 \mathrm{MeV} \mathrm{p}\end{array}$ & $\begin{array}{c}30 \mu \mathrm{A} \\
50-1000 \mu \mathrm{A} \\
1 \mathrm{~mA}\end{array}$ & $\begin{array}{c}p+B e \\
p+B e \text { or } C\end{array}$ \\
\hline Light Ion Linac & Injector for Synchrotron & $8 \mathrm{MeV} / \mathrm{amu}$ & $70-250 \mu \mathrm{A}$ & \\
\hline
\end{tabular}

(RFQ) linacs are competing with Cockroft-Walton accelerators as injectors to drift tube linacs as well as synchrotrons. In fact, the compact size of an RFQ injector for a medical synchrotron contributes greatly to making hospital-based synchrotrons practical. Light ion linacs are being developed as injectors to light ion synchrotrons for both basic research and radiation therapy but the size and cost of these systems are likely to prohibit commercialization in the near future.

\section{NEW APPLICATIONS}

Recent renewed interest in boron neutron capture therapy (BNCT) for treating advanced brain tumors has led to interest in accelerator-generated epithermal $(\sim 10 \mathrm{keV})$ neutrons. Two approaches have been taken. The first produces the neutrons as near threshold as possible to minimize the amount of moderating material required. Because the production cross sections are relatively low near threshold this approach requires high current accelerators in the $2.5-5 \mathrm{MeV}$ range. The second approach takes advantage of high yields from spallation sources at the expense of having to eliminate or moderate larger quantities of unwanted high energy spallation products. For a lithium production target the lower energy approaches use an RFQ or a tandem cascade accelerator. With a beryllium target a drift tube linac with an RFQ injector has been considered. For the spallation approach, both cyclotrons and linacs have been suggested. More details on accelerators for BNCT and relevant references are given in Table 2.
The increased demand for short-lived isotopes for positron emission tomagraphy (PET) has led to the development of compact accelerators providing protons, deuterons, or ${ }^{3} \mathrm{He}^{++}$with energies in the $4-10 \mathrm{MeV}$ range. One approach uses a tandem cascade accelerator and the other combines three RFQ's in tandem. Both technologies promise to become competitive with the "baby" cyclotrons now in use for these isotopes. More information and references are given in Table 2.

Because proton linacs usually operate in a high current mode they are not well matched to the low currents needed for proton therapy. One way to safely use an $\mathrm{H}^{-}$linac for therapy is to strip the $\mathrm{H}^{-}$using a laser, strip the resulting $\mathrm{H}^{\circ}$ using foils, and then direct the resulting protons to the therapy room. The proton intensity can be limited to nanoamps by limiting the power of the laser and the energy can be quantized by turning off the gradients in selected tanks. This scheme does not give the finely tunable energy variation obtainable with a synchrotron but passive scattering techniques can be used to make the final energy adjustments. It is a good method for physics laboratories with existing $\mathrm{H}^{-}$linacs to provide parasitic beam for patient treatment or research in beam delivery and dosimetry techniques. Another approach to using proton linacs for proton therapy takes advantage of the existing technology for electron linacs. Protons are accelerated from 70 to $250 \mathrm{MeV}$ using commercially available S-band radiofrequency power systems and accelerating cavities. The beam current is of the order of tens of nanoamps, which is 
Table 2

Applications in Which the Accelerator and/or the Targeting System are in the Proposal or Development Stages

\begin{tabular}{|c|c|c|c|c|c|}
\hline Accelerator & Application & Kinetic Energy & Average Current & $\begin{array}{c}\text { Production } \\
\text { Reaction }\end{array}$ & Reference \\
\hline Cyclotron & BNCT* & $70 \mathrm{MeV} \mathrm{p}$ & $80 \mu \mathrm{A}$ & $\overline{p+W}$ & 1 \\
\hline Proton Linac & $\begin{array}{c}\text { BNCT } \\
\text { BNCT } \\
\text { Proton Therapy }\end{array}$ & $\begin{array}{c}4 \mathrm{MeVp} \\
70 \mathrm{MeV} \mathrm{p} \\
70-250 \mathrm{MeV} \mathrm{H}^{-}\end{array}$ & $\begin{array}{c}? ? \\
180 \mu \mathrm{A} \\
10-40 \mu \mathrm{A} \mathrm{H}^{-} \text {primary }\end{array}$ & $\begin{array}{c}\qquad \mathrm{p}+\mathrm{Be} \\
\mathrm{p}+\mathrm{W} \\
\text { laser scattering }\end{array}$ & $\begin{array}{l}2 \\
3 \\
4\end{array}$ \\
\hline & Proton Therapy & $70-250 \mathrm{MeV} p$ & $10-270 \mathrm{nA}$ & & 5 \\
\hline RFQ Linac & $\begin{array}{l}\mathrm{PET}^{+} \text {isotopes } \\
\text { BNCT }\end{array}$ & $\begin{array}{c}8 \mathrm{MeV}^{3} \mathrm{He}^{++} \\
2.5 \mathrm{MeV} \mathrm{p}\end{array}$ & $\begin{array}{l}300 \mu \mathrm{A} \\
30 \mathrm{~mA}\end{array}$ & $\mathrm{p}+\mathrm{Li}$ & $\begin{array}{l}6 \\
7\end{array}$ \\
\hline Tandem Cascade & $\begin{array}{l}\text { PET isotopes } \\
\text { BNCT }\end{array}$ & $\begin{array}{l}3.7 \mathrm{MeV} \mathrm{p} \mathrm{or} \mathrm{d} \\
2.5 \mathrm{MeV} \mathrm{p}\end{array}$ & $\begin{array}{c}0.5-1.0 \mathrm{~mA} \\
5 \mathrm{~mA}\end{array}$ & $p+L i$ & $\begin{array}{l}8 \\
9\end{array}$ \\
\hline Coaxial Cascade & Angiography & $600 \mathrm{keV} \mathrm{e}^{-}$ & $1 \mathrm{~A}$ for $10 \mathrm{msec}$ & $\mathrm{e}-+\mathrm{BaB}_{6}$ or $\mathrm{CeB}_{6}$ & 10 \\
\hline
\end{tabular}

*Boron Neutron Capture Therapy

+Positron Emission Tomagraphy

appropriate for proton therapy. Both approaches are discussed in the references in Table 2.

Clinical interest in cardiac angiography bas led to development of a compact accelerator which generates $33 \mathrm{keV}$ gamma radiation. The proposal referenced in Table 2 uses a $600 \mathrm{keV}$ coaxial cascade accelerator to provide electrons which strike a target containing barium or cerium hexaboride. Commercialization of this accelerator is consistent with the traditional approach to the development of medical accelerators, in which the medical procedure is tested using an accelerator built for basic research and then the technology is developed to move the procedure to a clinical setting.

\section{REFERENCES}

[1] J.F. Crawford, H. Reist, H.Conde, K. Elmgren, T. Roennqvist, E.Grusell, B.Nilsson, O. Pettersson, P. Stromberg and B. Larsson, "Neutrons for Capture Therapy Produced by $72 \mathrm{MeV}$ Protons," in Progress in Neutron Capture Therapy for Cancer, B. J. Allen, D. E. Moore and B. V. Harrington, eds., Plenum Press, New York, 1992, pp. 129-132.

[2] C-K. Chris Wang and Brian R. Moore, "On the Study of Energy Spectra and Angular Distributions of the Neutrons Emitted from a Beryllium Target Bombarded with 4-MeV Protons for Neutron Capture Therapy," Proceedings of the Fifth International Symposium on Neutron Capture Therapy, Columbus, Ohio, 1992.

[3] Arlene J. Lennox, "Hospital-based proton linear accelerator for particle therapy and radioisotope production," Nucl. Instr. and Meth. B56/57 (1991) pp. $1197-1200$.

[4] "Proton Therapy at the SSC - Conceptual Design Summary," Superconducting Super Collider Laboratory Internal Report, April 6, 1992.
[5] R. W. Hamm, K. R. Crandall, J. M. Potter, "Preliminary Design of a Dedicated Proton Therapy Linac," Proceeding of the 1991 Particle Accelerator Conference, pp. 2583-2585.

[6] W. Hagan, W. Cornelius, P. Young, M. Schulze, R. Little, K Krohn, and J. Link, "A Helium-3 RFQ Accelerator for PET Tracer Production," Proceedings of the IVth International Workshop on Targetry and Target Chemistry, Paul Scherrer Institut Proceedings 92-01, August, 1992.

[7] T. P. Wangler, J. E. Stovall, T. S. Bhatia, C. K. Wang, T. E. Blue, and R. A. Gahbauer, "Conceptual Design of an RFQ Accelerator-Based Neutron Source for Boron Neutron-Capture Therapy," Proceedings of the 1989 Particle Accelerator Conference, IEEE \#89CH2669-0, pp. 678-680.

[8] R. E. Shefer, R. E. Klinkowstein, B. J. Hughey, and J. J. Welch, "Production of PET Radionuclides with a High Current Electrostatic Accelerator," Proceedings of the IVth International Workshop on Targetry and Target Chemistry, Paul Scherrer Institut Proceedings 92-01, August, 1992.

[9] R. E. Shefer, R. E. Klinkowstein, J.C. Yanch and G.L.Brownell, "An Epithermal Neutron Source for BNCT Using a Tandem Cascade Accelerator," in Progress in Neutron Capture Therapy for Cancer, B.J. Allen, D.E. Moore and B.V. Harrington, eds., Plenum Press, New York, 1992, pp. 119-122.

[10] R. E. Shefer, private communication and Herbert L. Manning, Ruth E. Shefer, Robert E. Klinkowstein and Charles A. Mistretta, "A $K_{\alpha}$ dual energy $x$-ray source for coronary angiography," Med. Phys. 18(5), pp. 880-893. 